\title{
Workplace Whistleblower Protection in the Visegrad Countries, France and Slovenia - Proposals for Changes ${ }^{1}$
}

\author{
Zbigniew Hajn², Dagmara Skupieńn \\ https://doi.org/10.18778/8220-639-5.11
}

\section{Introduction}

In the course of carrying out the grant titled "Workplace Whistleblower Protection in the Visegrad Countries, France and Slovenia" (WhistlePro), international team of legal experts ${ }^{4}$ developed proposals of potential improvements in the situation of workplace whistleblowers in the Visegrad countries. The research consisted in an analysis of the currently existing regulations in the Visegrad Group as well as of French and Slovenian legislation, an assessment of these regulations in light of international and European standards and development of proposals de lege ferenda. In the course of the research, cooperation was carried out with representatives of scientific centers, public institutions, civil society organizations, trade unions and enterprises.

The opportunity to introduce amendments to the existing provisions stems from the need to transpose the EU Whistleblower Protection Directive. ${ }^{5}$ The amendments may, and even should, go beyond the minimum standards required by the Directive.

The present chapter offers propositions of legislative changes, among others with regard to the methods of implementation, including relations between general

1 Z. Hajn: Introduction, Part I 1, 2.4, 4, Part II 1, 4, 5.1, 8, D. Skupień: Introduction, Part. I, 1, 2.1 2.3, 3, Part. II, 2, 3, 5, 6, 7, 9, 10, 11, Conclusion.

2 Professor, dr. hab., University of Lodz.

3 Dr hab., Professor at the University of Lodz.

4 G. Bargain, University of Tours; E. Bielak-Jomaa, University of Lodz; Z. Hajn, University of Lodz; A. Kun, G. Károli University of the Reformed Church in Hungary (KRE); J. Morávek, Charles University in Prague; A. Olšovská, Trnava University in Trnava; J. Pichrt, Charles University in Prague; D. Senčur-Peček, University of Maribor; D. Skupień, University of Lodz; R. Szuchy, Gáspár Károli University of the Reformed Church in Hungary (KRE); P. Varga, Trnava University in Trnava; V. Zoričáková, Trnava University in Trnava.

5 Directive (EU) 2019/1937 of the European Parliament and of the Council of 23 October 2019 on the protection of persons who report breaches of Union law, OJ L 305, 26.11.2019, p. 17-56, further referred to as the EU Whistleblower Protection Directive. 
principles of whistleblowing and sectorial provisions, the personal and the material scope of whistleblowing, which should involve protection against negative consequences, the proper organisation of internal and external reporting channels, methods of providing whistleblowers with effective means of protection against retaliatory actions, measures of support for whistleblowers, matters concerning confidentiality and issues concerning criminal liability for disclosing the whistleblower's personal data and hindering or precluding reporting breaches.

\section{Current legislation}

\section{Introductory remarks}

The current provisions on whistleblower protection in the Visegrad countries, France and Slovenia vary with regard to the methods and scope. The law of all above-mentioned countries is influenced by international law, especially the Council of Europe Conventions as well as by sectorial provisions concerning whistleblowing adopted at the European Union level. Moreover, Slovakia as well as France and Slovenia ratified ILO Termination of Employment Convention, 1982 (No. 158), according to which the filing of a complaint or the participation in proceedings against an employer involving alleged violation of laws or regulations or recourse to competent administrative authorities shall not constitute valid reasons for termination of the employment (Article 5 point c) ${ }^{6}$.

None of the legislations, however, provides fully effective protection to whistleblowers or is fully compatible with the EU Whistleblower Protection Directive.

It should be mentioned, that despite special laws concerning whistleblowers adopted in certain analysed legislations and general rules applying to persons reporting the breaches, there are still fears linked with whistleblowing not to be perceived as a 'traitor' or a 'snitch', as well as quite often the lack of knowledge, how and to

6 See A. Olšovská, V. Hrušovská, Whistleblowing na pracovisku - právna úprava, teória a prax na Slovensku - Whistleblowing at the workplace - legislation, theory and practice in Slovakia, [in:] J. Pichrt (ed.), Whistleblowing, Wolters Kluwer ČR, Prague 2013.

7 Compare report of research prepared for the European Commission, Special Eurobarometer 502, 'Corruption' Report, (June 2020), https://europa.eu/eurobarometer/surveys/detail/2247 accessed 01/09/2021, according to which $37 \%$ of respondents from Denmark and $30 \%$ from Poland would not decide to report corruption in order not to be perceived as a 'traitor', $p$. 119, See also about these fears: Oživeni, Whistleblowing, June 2020, p. 15-16, https://www. oziveni.cz/wp-content/uploads/2021/01/v4-Whistleblowing_EN.pdf, accessed 01/09/2021 or the survey conducted in Poland by Batory Foundation and Forum Idei, G. Makowski, M. Waszak, Gnębieni, podziwiani i... zasługujący na ochronę. Polacy o sygnalistach. Raport z badania opinii publicznej (Oppressed, admired and... deserving protection. Poles about whistleblowers. A report 
which authorities the breach of law should be reported. According to the survey of the public opinion conducted within the EU, only $44 \%$ of Europeans know how to report corruption. The level of knowledge in this aspect is lower than the European average in France and Poland (42\%), in the Czech Republic (41\%), Slovakia (37\%) and Hungary (27\%) but higher in Slovenia (48 \%). ${ }^{8}$

\section{Legislation in the Visegrad Countries}

\subsection{The Czech Republic}

Although several legislative drafts have been put forward since 2012, no law that would comprehensively regulate the procedures of whistleblowing and matters related to whistleblower protection has been adopted in the Czech Republic. ${ }^{9}$ So far, whistleblower protection has been based on general principles of law, including labour law ${ }^{10}$ and case law of the Czech Constitutional Court. ${ }^{11}$ Organizational matters related to reporting, also anonymously, crimes committed in connection with work as a civil servant are stipulated by Government Regulation No. 145/2015 Coll., ${ }^{12}$ issued on the basis of $\$ 205(d)$ of the Czech code of civil service. ${ }^{13}$ Works are currently underway on a draft legislation developed by the Department for Conflict of Interest and Fight against Corruption of the Ministry of Justice, whose purpose is to transpose the EU Whistleblower Protection Directive in the Czech Republic.

from the public opinion poll), Warsaw 2019, p. 13, https://www.sygnalista.pl/wp-content/ uploads/2019/06/Internet_Raport_sygnalisci_12-06.pdf, accessed 01/09/2021. On the other hand, opinion polls in countries covered by the analysis show positive assessments of whistleblowers, see e.g.: Report prepared for Transparency International Slovakia Záverečná správa z kvantitatívneho prieskumu pre Transparency International Slovensko, Focus Marketing and Social Research, May 2016, p. 13, https://transparency.sk/sk/prieskumy/, accessed 01/09/2021.

8 Special Eurobarometer 502, 'Corruption' Report (June 2020), p. 115, https://europa.eu/eurobarometer/surveys/detail/2247, accessed 01/09/2021.

9 Cf. J. Pichrt, J. Morávek in this monograph.

10 Labour Code, No. 262/2006 Coll.

11 See J. Pichrt, J. Morávek, Whistleblowing: National Report for the Czech Republic, [in:] G. Thüsing, G. Forst, (eds.), Whistleblowing - A Comparative Study, Springer, Cham 2016, pp. 115-123.

12 Nařizení Vlády ze dne 15. června 2015 o opatřeních souvisejících s oznamováním podezření ze spáchání protiprávního jednání ve služebním úřadu, 145/2015 Coll.

13 See Zákon č. 234/2014 Sb. ze dne 1. rijna 2014 o státní službě. For more on proposals concerning a proper regulation of whistleblowing in civil service, see J. Morávek, [in:] J. Pichrt et al., Zákon o státni službě, Komentár (Civil Service Act, Commentary), $1^{\text {st }}$ ed., Wolters Kluwer, Prague 2015, pp. $720-724$. 


\subsection{Hungary}

In Hungary, whistleblowing is regulated by the Act CLXV of 2013 on complaints and public interest disclosures (further referred to as the Pkbt.). ${ }^{14}$ Pursuant to $\$ 1$ (1) Pkbt., public authorities and local government entities examine complaints and public interest disclosures. Following $\$ 4$ (1) Pkbt., a public interest disclosure may be made also via a secure electronic system for public interest disclosures guaranteeing anonymity of a whistleblower to the investigating organs. The system for submitting and registering public interest disclosures is maintained by the Commissioner for Fundamental Rights. Matters related to whistleblowing in the public administration sector are regulated by the Government Regulation 50/2013 on the system of integrity management at public administration bodies and the procedural rules of receiving whistleblowers' reports. The means of whistleblower protection are provided by the Act LXXX of 2003 on legal aid. The present regulations are criticised for many reasons, especially for the lack of clarity concerning the support measures, no rules defining which authority shall establish that the whistleblower is at risk, no rules concerning guarantees that a person can benefit from a protection and no psychological support to whistleblowers provided by the Government. ${ }^{15}$

\subsection{Poland}

Poland has no one act that would provide a comprehensive regulation of workplace whistleblower protection. The obligation to establish internal channels and the rules of reporting irregularities are specified for some sectors of business activity, which results from the influence of EU regulations. There is no institution in Poland that would direct whistleblowers to appropriate external channels or offer them legal advice and information on their rights. The rules of whistleblower protection are inferred from various dispersed legal acts, including the labour code, ${ }^{16}$ as well as

14 See the English version of the Act: http://www.ajbh.hu/documents/14315/130159/Act_CLXV_ of_2013_.pdf/faa3e557-8e16-473f-1fa9-539e7cdb0f22, accessed 01/09/2021. About this act see H. Szewczyk, Whistleblowing. Zgłaszanie nieprawidłowości w stosunkach zatrudnienia (Whistleblowing, Disclosing irregularities in employment relationships), Scholar, Warszawa 2020, pp. 101-103.

15 See A. Kun in the present monograph as well as European Network of National Human Rights Institutions, State of the Rule of Law in the European Union, Reports of National Human Rights Institutions, 2021, p. 305 https://ennhri.org/news-and-blog/ennhri-publishes-its-second-annual-report-on-the-state-of-the-rule-of-law-in-europe/, accessed 01/09/2021.

16 See D. Skupień, Whistleblowing in Poland According to Legislation and Case Law, [in:] G. Thüsing, G. Forst (eds.), Whistleblowing - A Comparative Study, Springer, Cham 2016, pp. 221-224 and, by the same author, The legal protection of whistleblowers, [in:] B. Lewaszkiewicz-Petrykowska (ed.), Poland in Rapports polonais, XIX Congrès international de droit comparé, Vienne, 20-26 VII 2014, Lodz University Press, Lodz 2014, pp. 258-261. 
the case law of the Supreme Court on the acceptable criticism of the employer by the worker, which was developed on the basis of labour law cases initiated in situations when an employer terminated the employment of a whistleblower-worker. The legislation needs to be improved chiefly on account of deficiencies such as: lack of a legal definition of the whistleblower or the material scope of breaches of law or irregularities whose disclosure would qualify for protection, lack of clarity with regard to authorities competent for examining reports made through external channels, the follow-up character of protection against termination of employment, the applicability of protection mainly to workers hired under an employment relationship for an indefinite period, or the lack of clear rules concerning the burden of proof in matters concerning alleged discriminatory actions against whistleblowers. ${ }^{17}$

\subsection{Slovakia}

Slovakia, like Hungary, has chosen the path of standardizing the situation of whistleblowers in one main law. The first Slovak law on this matter was adopted in 2014 (Act No. 307/2014 Coll. on certain measures relating to reporting anti-social activities and on amending and revising certain acts) as part of the government's programme to strengthen whistleblower protection, taking into account the country's international legal obligations. ${ }^{18}$ This law was replaced in 2019 by the current Law No. $54 / 2019$ Coll. on the protection of persons who disclose anti-social activities and on the amendment and supplementation of certain laws. ${ }^{19}$ The new act strengthened the position of whistleblowers in criminal proceedings, increased protection, and established a nationwide, independent administrative body for the protection of whistleblowers. As a result, there are no special sectorial acts covering specific areas of law in the Slovak Republic, but there is one general act protecting whistleblowers in both the private and the public sector. However, the act does not cover all cases of whistleblowing requiring protection. For this reason, anti-discrimination legislation also plays an important role in protecting whistleblowers who report anti-social behaviour. An amendment to the existing law is expected as a result of the obligation to transpose the Directive. ${ }^{20}$

17 Cf. D. Skupień in this chapter as well as $Ł$. Bolesta, In Search of a Model for the Legal Protection of a Whistleblower in the Workplace in Poland, Peter Lang, Berlin 2020, pp. 135-139 or H. Szewczyk, Whistleblowing. Zgłaszanie nieprawidłowości w stosunkach zatrudnienia (Whistleblowing, Disclosing irregularities in employment relationships), op. cit., pp. 334-337.

18 For more details see T. Mičudová, Zákon o oznamovaní protispoločenskej činnosti. Komentár (Act on reporting anti-social activities. Commentary), Wolters Kluwer, Bratislava 2016.

19 Zákon z 30. januára 2019 o ochrane oznamovatel'ov protispoločenskej činnosti a o zmene a doplnení niektorých zákonov.

20 Cf. P. Varga, V. Zoričáková in this monograph. 


\section{Legislation in France}

France currently has three separate whistleblowing systems. One stipulates the principles of whistleblower protection and methods of reporting breaches in private or public legal persons with at least fifty workers as well as in commune, department and region offices with at least 10,000 inhabitants under Articles 7-15 of Loi Sapin $2^{21}$ and the implementing provisions to the act. ${ }^{22}$ Another is a system of reporting acts of corruption and trading in influence committed in France or abroad in partnerships or companies with at least 500 workers or in groups of undertakings with their registered seats in France with at least 500 workers whose turnover or consolidated turnover exceeds EUR 100 million (Article 17 of Loi Sapin 2). In turn, Loi $n^{\circ}$ 2017-399 du 27 mars 2017 relative au devoir de vigilance des sociétés mères et des entreprises donneuses d'ordre (Act No. 2017-399 of 27 March 2017 on the corporate duty of vigilance for parent and instructing companies) introduced into the commercial code (Code de commerce) the duty to establish a vigilance plan in order to assess the risk and counteract serious violations of human rights, fundamental freedoms as well as of provisions on health and safety of persons and environmental protection. One of the elements of the plan is to establish, in cooperation with representative trade unions in the company, a mechanism of reporting and receiving reports about risks or breaches. The above obligation applies to partnerships and companies with their registered seats in France and with at least five thousand direct or indirect workers at their seat and in their subsidiaries as well as to partnerships and companies with their registered seats in France or abroad and with at least ten thousand direct or indirect workers at their seat and in their subsidiaries. Whistleblower protection is complemented by labour law provisions, ${ }^{23}$ including anti-discrimination regulations. A special role in the process of reporting breaches is played by Défenseur des droits (Defender of Rights), which has informational functions with regard to whistleblowing and refers whistleblowers' reports to the competent external authorities. ${ }^{24}$

21 Loi n² 2016-1691 du 9 décembre 2016 relative à la transparence, à la lutte contre la corruption et à la modernisation de la vie économique. See P. Adam, À propos de la protection générale des lanceurs d'alerte dans l'entreprise privée (Commentaire de la loi dite « Sapin II » du 9 décembre 2016), Revue de jurisprudence sociale, 5/2017.

22 Décret n 2017-564 du 19 avril 2017 relatif aux procédures de recueil des signalements émis par les lanceurs d'alerte au sein des personnes morales de droit public ou de droit privé ou des administrations de l'État.

23 Cf. G. Bargain in this monograph as well as $Ł$. Bolesta, In Search of a Model for the Legal Protection of a Whistleblower in the Workplace in Poland, op. cit., pp. 67-70, A. Rommel, Ochrona sygnalistów we francuskim systemie prawnym (Whistleblower Protection in the French Legal System), [in:] B. Baran, M. Ożóg (eds.), Ochrona sygnalistów. Regulacje dotyczqce osób zgłaszających nieprawidłowości (Whistleblower Protection. Regulations Concerning Persons Reporting Irregularities), Wolters Kluwer, Warsaw 2021, pp. 197-204.

24 See Article 4 of Loi organique No. 2011-333 du 29 mars 2011 relative au Défenseur des droits (organic law No. 2011-333 of 29 March 2011 on the human rights defender), JORF No. 0075 


\section{Legislation in Slovenia}

In Slovenia, there is no general or specific legislation providing comprehensive protection for whistleblowers. ${ }^{25}$ Employees and public servants who report unlawful or harmful conduct enjoy protection only under specific laws, some of which were issued as a result of international obligations binding on the country. They also benefit from general protection under labour law. Leading the way is the Integrity and Prevention of Corruption Act 2010 (Zakon o integriteti in preprečevanju korupcije), which regulates the reporting of corruption and protection of the person reporting corruption, the reporting of unethical or illegal conduct and measures to protect the person making the report, implementing the Council of Europe Civil Law Convention on Corruption and the United Nations Convention against Corruption. Furthermore, reporting is regulated by the Slovenian State Holding Company Act (Zakon o slovenskem državnem holdingu), with the proviso that the protection of persons who report illegal practices thereunder is governed by the provisions of the Integrity and Prevention of Corruption Act 2010. Moreover, Slovenia has a number of laws implementing European Union regulations and directives in the field of banking, insurance, stock exchange, etc., which make it the responsibility of Member States to regulate the obligations of legal entities and their supervisory authorities to establish internal whistleblowing channels and ensure the protection of whistleblowers. These issues are regulated by acts on: banking (Zakon o bančništvu), insurances (Zakon o zavarovalništvu), financial instruments market (Zakon o trgu finančnih instrumentov), investment funds and management companies (Zakon o investicijskih skladih in družbah za upravljanje), prevention of money laundering and terrorist financing (Zakon o preprečevanju pranja denarja in financiranja terorizma), and trade secrets (Zakon o poslovni skrivnosti). However, it is pointed out that Slovenian labour law does not provide special protection for whistleblowers against retaliation by employers. However, the Labour Relations Act (Zakon o delovnih razmerjih) provides all employees (including public employees) with protection against unlawful practices of employers, such as harassment and mobbing, and wrongful termination of employment. In turn, the Law on Inspection (Zakon o inšpekcijskem nadzoru) imposes on inspectors the obligation to protect the source of the report or the source of other information. The Law on Mass Media (Zakon o medijih, ZMed), which guarantees journalists the right not to disclose sources, as well as the Law on

of 30 March 2011 amended by Loi organique No. 2016-1690 du 9 décembre 2016 relative à la compétence du Défenseur des droits pour l'orientation et la protection des lanceurs d'alerte.

25 See D. Senčur-Peček in this monograph and also by the same author: Protection of Persons Reporting Corruption and Other Whistleblowers in the Republic of Slovenia, [in:] G. Thüsing, G. Forst (eds.), Whistleblowing - A Comparative Study, Springer, Cham 2016, pp. 263-277, and Delovnopravno varstvo žvižgačev (Labour law protection for whistleblowers), Delavci in delodajalci, 2-3/2015, pp. 223-248 as well as A. Nabernik, Preden prijavim goljufijo, želim vedeti, kakšno zaščito bom dobil (Before I report fraud, I want to know what protection I will get), Pravna praksa, 33/2019, pp. 22-32. 
Witness Protection (Zakon o zaščiti prič, ZZPrič) and the Criminal Code (Kazenski zakonik, KZ-1) also indirectly address the protection of whistleblowers.

The definition of unlawful, unfair or unethical practices, the methods of reporting and the protection of whistleblowers at the employer level are further regulated by so-called codes of conduct, codes of ethics or corporate integrity policies of larger companies, many of them state-owned. Most of them are also signatories to the 2014 Slovenian Corporate Integrity Guidelines developed by the Chamber of Commerce and Industry of Slovenia, the Managers' Association of Slovenia and the Slovenian Directors' Association upon the initiative of the Faculty of Economics, University of Ljubljana.

Due to the fragmentary nature of the legal protection of whistleblowers, it is proposed to implement the Directive through the adoption of a special law. Proposals to this effect have already been submitted to the Slovenian government by the Ministry of Justice. ${ }^{26}$ Representatives of legal doctrine also put forward their own proposals. ${ }^{27}$

\section{Proposals for Changes}

\section{Method of transposition of the EU Whistleblower Protection Directive}

Currently, there is a patchwork of legal regulations concerning whistleblowing and the status of whistleblowers in the European Union Member States. EU Directive 2019/1937 establishes common minimum standards for the protection of whistleblowers in the areas covered by its scope..$^{28}$ That is also the basic scope of its transposition into the law of the Member States. One can, of course, stop there. However, transposition provides an invaluable opportunity to create, throughout the Union and in the individual Member States, a system of whistleblowing and protection for whistleblowers that goes beyond the minimum required by the Directive. According

26 See Vlada R.S., Odgovor na poslansko vprašanje, No. 00104-4/2020/6, of 6/2/2020, http:// vrs-3.vlada.si/MANDAT18/VLADNAGRADIVA.NSF/71d4985ffda5de89c12572c3003716c4/ 66270c5c8633b33ec125850600373686/\$FILE/odg_21.pdf, accessed 01/09/2021.

27 Compare D. Senčur-Peček in this monograph, I. Vuksanović, Poziv za specialno zakonsko ureditev "žvižgačev" (Call for special regulation of "whistleblowers"), Pravna praksa, 2010/45, p. 8, or A. Sedlar, Zgodovinska prelomnica pri zaščiti žvižgačev $v$ EU (A historic turning point for whistleblower protection in the EU), Pravna praksa, 2019/13, pp. 6-8.

28 This applies to the articulated part of the Directive, as the recitals have no binding force; see Case C-162/97, Nilsson, (1998) ECLI:EU:C:1998:554, para 54, and are not transposed. However, they are important for the application and interpretation of its provisions, so taking them into account is important for the correctness of the transposition; see J. Maśnicki, Metody transpozycji dyrektyw (Methods of directives' transposition), Europejski Przegląd Sądowy, 2017, No. 8, p. 5. 
to Article 25 of the Directive, Member States may adopt or maintain provisions which are more favourable in terms of the rights of whistleblowers. At the same time, the implementation of the Directive must not lead to a reduction in the already existing level of protection of their rights.

Member States are not bound by the limitations on EU competence set out in Article 2(1) of the Directive. It follows from Articles 2 and 25 that the Directive lays down common minimum standards of protection for persons who only report breaches of Union law. However, Member States may decide to extend the application of national provisions to other areas. In the light of recital 5, such extension should be made with a view to ensuring a comprehensive and consistent framework of protection for whistleblowers at the national level. The extension of protection was also encouraged by the European Commission, which pointed out that "a comprehensive approach is necessary to recognise the significant contribution of whistleblowers in preventing and combating unlawful activities detrimental to the public interest, and to ensure that they are adequately protected across the EU" ${ }^{29}$

The Directive contains no indication as to the method of its implementation other than a general indication of the importance of ensuring balanced and effective protection of whistleblowers (recital 1). Therefore, it does not matter whether a Member State regulates the protection of whistleblowers in one or more legal acts. However, it seems useful to assume that implementation should ensure a comprehensive and coherent whole, in which reporting and disclosure channels, investigation and correction mechanisms, and legal measures to protect and support whistleblowers effectively interact. ${ }^{30}$ Therefore, just as the Directive is currently a lex generalis for the protection of whistleblowers and leaves room for other, more specialized regimes to apply where such provisions exist in the EU, e.g. for money laundering, a national law on whistleblowing could be a lex generalis for specific provisions. In the countries surveyed, the principle of a single general act has been adopted in Slovakia and Hungary.

The possibility of using collective agreements as a means of transposing the Directive raises more questions. First of all, such a transposition route is permissible if the collective agreements are recognized as sources of generally applicable law in the legal system of the Member State. ${ }^{31}$ Besides, the Treaty on the Functioning of the European Union provides this possibility for directives adopted pursuant to its Article 153, which is not the case for Directive 2019/1937. Another issue, on the other hand, is how Member States implement their obligation to ensure that legal entities establish channels and procedures for internal notification and follow-up

29 European Commission (2018), Communication from the Commission to the European Parliament, the Council and the European Economic and Social Committee, Strengthening whistleblower protection at EU level, COM (2018) 214 final, https://ec.europa.eu/info/sites/info/files/ placeholder_10.pdf, accessed 01/09/2021.

$30 \mathrm{Cf}$. Council of Europe, Protection of whistleblowers, Recommendation CM/Rec(2014)7 and explanatory memorandum, 2014, https://rm.coe.int/16807096c7, p. 19, accessed 01/09/2021.

31 More: S. Prechal, Directives in EC Law, Oxford University Press, Oxford 2005, pp. 85-87. 
(Articles 8 and 9 of the Directive). The legal instrument introducing these channels and procedures in individual organizations may be by-laws, orders or similar internal acts. They may also be collective agreements, in particular where the internal channels are only open to employees - Article 8(2) of the Directive. Whichever of these instruments is chosen, the statutory provisions implementing the Directive should give them binding legal effect so that they can be treated as a source of rights and obligations.

Various types of soft law, such as company and group codes of conduct, codes of ethics or corporate integrity policies, can also be of ancillary importance in defining unfair or unethical practices, establishing methods for reporting and protecting whistleblowers.

Both collective agreements and soft law acts may be more relevant in areas not covered by EU law or national whistleblowing legislation. Here too, however, they must comply with the requirements of general legal provisions relevant to the protection of whistleblowers.

\section{The relation between general and sectorial provisions}

Pursuant to Article 3(1) of the EU Whistleblower Protection Directive, if specific rules on the reporting of breaches are stipulated in the sector-specific EU acts listed in Part II of the Annex, those specific rules apply. The provisions of the EU Whistleblower Protection Directive are applied to the extent to which the matter is not mandatorily regulated in those sectorial Union acts.

The acts listed in Part II of the Annex may be classified by sectors into those concerning: financial services, products and markets, preventing money laundering and terrorist financing, transport safety, and protection of the environment. Typically, the following rules of establishing external and internal reporting channels are specified in those provisions: autonomous, special channels that guarantee the confidentiality of reports and the protection of the personal data of the reporting person and of the person concerned. ${ }^{32}$ In some instances, anonymous reports ${ }^{33}$ as

32 See e.g. Article 24(1)(c) of Regulation (EU) 2015/2365 of the European Parliament and of the Council of 25 November 2015 on transparency of securities financing transactions and of reuse and amending Regulation (EU) No 648/2012, OJ L 337, 23.12.2015, pp. 1-34.

33 See Article 5(1) (a) of the Commission Implementing Directive (EU) 2015/2392 of 17 December 2015 on Regulation (EU) No 596/2014 of the European Parliament and of the Council as regards reporting to competent authorities of actual or potential infringements of that Regulation, $\mathrm{OJ}$ L 332, 18.12.2015, pp. 126-132, or Article 21(2) of Regulation (EU) 2015/847 of the European Parliament and of the Council of 20 May 2015 on information accompanying transfers of funds and repealing Regulation (EC) No. 1781/2006 (Text with EEA relevance), OJ L 141, 5.6.2015, pp. $1-18$, or Article 22 of the Directive 2013/30/EU of the European Parliament and of the Council 
well as financial incentives for whistleblowers ${ }^{34}$ are permitted. Moreover, sector-specific provisions include fairly laconic stipulations on the obligation to provide protection of whistleblowers from retaliatory actions, discrimination and other forms of unfair treatment. ${ }^{35}$ As a prerequisite of granting protection against negative consequences to the reporting person, some sectorial acts explicitly require that they act in good faith. ${ }^{36}$

In the light of Article 3(1) of the EU Whistleblower Protection Directive, the application of national acts that transpose the EU Whistleblower Protection Directive should be extended to reporting persons within the sectors listed in part II of the Annex to the Directive, while at the same time retaining the distinctness resulting from binding sector-specific provisions. In particular, it is necessary to ensure such persons minimum standards of protection resulting from the EU Directive 2019/1937 as well as to apply to specific sectors minimum requirements with regard to the structure of external reporting channels and to the obligations of the competent authorities as well as to the form of internal channels if provided in the sectorial provisions. Some sectorial provisions, in turn, e.g. concerning the anonymity of the reports, the mechanisms of ensuring data confidentiality or the use of financial incentives in the event of a new report, which result in administrative or criminal sanctions imposed against the entities that commit the breaches, may be a source of inspiration for the transposition of the EU Whistleblower Protection Directive.

\section{Material Scope of Whistleblowing}

The EU Whistleblower Protection Directive focuses on the protection of persons who report breaches of Union law listed in Article 2. However, it leaves certain freedom to the Member State authorities in terms of the possibility to extend the

of 12 June 2013 on safety of offshore oil and gas operations and amending Directive 2004/35/ EC Text with EEA relevance, OJ L 178, 28.6.2013, pp. 66-106.

34 See Article 32(4) of Regulation (EU) No 596/2014 of the European Parliament and of the Council of 16 April 2014 on market abuse (market abuse regulation) and repealing Directive 2003/6/ EC of the European Parliament and of the Council and Commission Directives 2003/124/EC, 2003/125/EC and 2004/72/EC Text with EEA relevance, OJ L 173, 12.6.2014, p. 1-61.

35 Cf. Article 24(1)(b) of Regulation (EU) 2015/2365 of the European Parliament and of the Council of 25 November 2015 on transparency of securities financing transactions and of reuse and amending Regulation (EU) No 648/2012.

36 Cf. e.g. Article 37 of Directive (EU) 2015/849 of the European Parliament and of the Council of 20 May 2015 on the prevention of the use of the financial system for the purposes of money laundering or terrorist financing, amending Regulation (EU) No 648/2012 of the European Parliament and of the Council, and repealing Directive 2005/60/EC of the European Parliament and of the Council and Commission Directive 2006/70/EC, OJ L 141, 5.6.2015, p. 73-117. 
scope of protection under national law with regard to areas or acts not covered by the Directive (Article 2(2)).

It seems that the scope of the future legislation that will transpose the Directive should be extended in such a way that it covers "breaches of law" in general ${ }^{37}$, with regard to European Union law and international, national and foreign law. In practice, on account of the broad scope of harmonization or even unification of legal standards, it may be difficult to distinguish between breaches that concern Union law and not national law. Moreover, it would be beneficial to provide protection also to persons who report breaches of foreign law, which is particularly important in the context of groups of undertakings.

Following Article 5(1)(ii) and recital 42 of the EU Whistleblower Protection Directive, the concept of breach covers also abusive practices as defined by the case law of the Court, i.e. acts or omissions that do not seem to be unlawful in formal terms, but are not compatible with the object or the purpose of the law. It would appear useful to define the notion of abusive practices in national legislation by adopting the above-mentioned definition and also covering by the scope of national provisions abusive practices concerning legal acts in general, not only abuses of EU legal acts and areas falling within the material scope referred to in Article 2 of the Directive.

Furthermore, the material scope of breaches should be extended to breaches of codes of ethics, which are binding in some sectors or professions under applicable legislation. Moreover, it seems that future legislation should allow for the possibility for entities establishing internal channels to expand the material scope of breaches which may be reported through these channels under internal regulations applicable in a specific organization, such as CSR documents or codes of ethics. Such broadening of the material scope should result in extending the protection to reporting persons that are defined as such within a specific organization.

According to Article 5(2) of the Directive, the material scope should further cover reports of past (with no time limitation), current and potential breaches.

In light of Article 3(2) of the Directive, it shall not affect the responsibility of Member States to ensure national security or their power to protect their essential security interests. However, matters concerning defence, security and classified information shall not be excluded from the material scope, but rather specific reporting schemes for these issues should be provided. ${ }^{38}$

37 See M. Łaga, Unormowania dotyczące sygnalizacji - wzmacnianie demokracji w miejscu pracy (Regulations concerning whistleblowing - strengthening democracy in the Workplace), [in:] Z. Hajn, M. Kurzynoga (eds.), Demokracja w zakładzie pracy. Zagadnienia prawne (Democracy in the workplace. Legal aspects),, Wolters Kluwer, Warsaw 2017, p. 482.

38 See Transparency International, Building on the EU Directive for Whistleblowing Protection. Analysis and Recommendations, Position Paper 1/2019, p 3. 


\section{Personal Scope of Protection}

\subsection{General comments}

Protection of whistleblowers is subordinate to the objective, expressed in Article 1 of the Directive, of protecting the public interest by improving the enforcement of the law and Union policies in specific areas. Ensuring a high level of protection for whistleblowers is intended to serve that purpose. This objective, suitably modified if the scope of the areas to which whistleblowing applies is extended, should be taken into account in the provisions implementing the Directive. Protection of whistleblowers can be direct, when it is granted directly to the whistleblower, and indirect, when retaliatory action is taken against persons related to the whistleblower (recital 41 of the Directive).

\subsection{Personal scope of direct protection}

The Directive defines a whistleblower as a "reporting person". Direct protection is granted to any person who is a reporting person within the meaning of the Directive and fulfils the conditions for enjoying protection set out therein. In accordance with Article 5(7), this is a natural person who reports or publicly discloses information on breaches acquired in the context of their work-related activities.

In order to be protected, a whistleblower must, according to Article 6 of the Directive, have reasonable grounds to believe that the information was true at the time of reporting and falls within the scope of the Directive; in addition, they must not be recognized or registered as paid whistleblower. Whistleblowers may be excluded from protected whistleblowing if they make complaints solely in their private interest related to a conflict with another person. Some of these characteristics and conditions for protection raise questions in the context of implementation or are criticized.

The requirement that the whistleblower be a natural person excludes legal persons from the group of protected entities. We believe that this limitation is accurate. The purpose of the Directive is, as indicated above, to protect the public interest in improving respect for the law by protecting whistleblowers in the context of their work. The special reporting procedures, support measures and protection against retaliation provided for in the Directive are tailored to serve this purpose. This is in itself a sufficiently important, distinct and specific area for combating breaches of the law that threaten society. On the other hand, whistleblowing by legal entities, such as for example contractors of the wrongdoer or civil society organizations combating fraud and corruption, would, if the existing provisions are considered insufficient, require separate legislation. Another issue is the possibility of protecting organizations such as trade unions or other civil society organizations that provide 
assistance to the whistleblower. This issue is related to the protection of facilitators and will be discussed in further comments.

The implementation work should also pay attention to the characteristic of the whistleblower, which according to Article 5(7) is the disclosure of information in a context of their work-related activities. This concept is explained in the glossary of the Directive in Article 5(9). It follows from this clarification that a whistleblower is protected if they receive information in circumstances or situations related to their work or professional activities through which they have had contact with the institution concerned by the disclosure. Moreover, they are protected from retaliation related to that activity, although the retaliation itself may be taken outside the work-related context (recital 97). The inclusion of this term in the glossary of the Directive means that it should be understood uniformly throughout the Directive. Thus, if the Directive defines, for example, a facilitator as "a person who assists a reporting person in a work-related context", it means that they assist the whistleblower in circumstances related to the whistleblower's professional activity and not their own. Moreover, it should be concluded from the wording of the provision under consideration that information the disclosure of which is subject to protection under the Directive must be obtained in connection to the circumstances of the whistleblower's work, whereas such a connection does not have to characterize the information itself.

A further condition for the recognition of a whistleblower as a protected person, which is the requirement that the whistleblower must have reasonable grounds to believe that the information was true at the time of reporting and falls within the scope of the Directive, means that the Directive rejects the good faith test often used to protect a whistleblower who has disclosed information about misconduct that has turned out to be wrong. Instead, the Directive introduces a "reasonable grounds to believe" test, which does not refer to the whistleblower's belief in the veracity of the information, but to the judgment that would be made by a reasonable and objective observer in the whistleblower's position, i.e. one occupying a comparable position and possessing comparable knowledge and experience. Furthermore, the whistleblower does not have to provide authentic information to benefit from protection; it is sufficient that has a reasonable suspicion that wrongdoing has occurred (Article 5 (2)). As a result, the motives of whistleblowers should not be relevant in deciding whether they should receive protection (recital 32). In such a situation, the introduction in the implementing provisions of a requirement that the whistleblower act in good faith would constitute an impermissible, in the light of Article 25(1), adoption of provisions less favourable to whistleblowers than the standard set out in the Directive. An analogous test was adopted to assess the situation where the whistleblower mistakenly assumed that the reported breach was covered by the Directive. However, persons who intentionally and knowingly provided incorrect or misleading information at the time of reporting do not benefit from protection ${ }^{39}$ and should be subject to effective, proportionate and dissuasive sanctions and be liable

39 Recital 32. 
for damages caused by such conduct. ${ }^{40}$ Special attention should be paid to the situation when a whistleblower makes a report without a proper understanding of whether there are reasonable grounds for reporting and whether the notified breach is covered by the Directive and, for example, reports information that is already publicly known or unfounded rumours or hearsay. In such a situation, according to recital 43 , the whistleblower is not entitled to protection. We believe that the denial of protection should be limited only to the case where the misjudgement is due to the whistleblower's gross negligence.

It is sometimes argued that there can be no whistleblowing when disclosure is required by law on pain of sanction ${ }^{41}$. We believe this view is wrong. Accepting it would mean depriving whistleblowers of protection in all those cases where the law infers an employee's duty to inform about irregularities from the employee's duty of loyalty to the employer, from the employee's duty of care for the good of the workplace or from the civil servant's duty of care for the public good. On the other hand, we consider it appropriate to point out in recital 30 that the Directive should not apply to cases in which persons who, having given their informed consent, have been identified as informants or registered as such in databases managed by authorities appointed at national level, such as customs authorities, and report breaches to enforcement authorities in return for reward or compensation. Such reports are made pursuant to specific procedures that aim to guarantee the anonymity of such persons in order to protect their physical integrity and that are distinct from the reporting channels provided for under the Directive. At the same time, in accordance with recital 62, the Directive should also grant protection where Union or national law requires the reporting persons to report to the competent national authorities, for instance as part of their job duties and responsibilities or because the breach is a criminal offence.

The Directive refers to the public interest in a number of recitals, underlines the importance of whistleblowing for the protection of the interests of the Union and of Member States, and even links whistleblowing to the protection of the public interest, ${ }^{42}$ but does not make protection of whistleblowers conditional on acting in that interest. ${ }^{43}$ Only the admissibility of public disclosure has been made subject in certain situations to an action in the public interest. ${ }^{44}$ Therefore, making the

40 Article 23(2) and recital 102.

41 D. Banisar, Whistleblowing: International Standards and Developments, [in:] I. Sandoval, (ed.), Corruption and Transparency: Debating the Frontiers Between State, Market and Society, World Bank-Institute for Social Research, UNAM, Washington, D.C, 2011, https://ssrn.com/ abstract $=1753180$, p. 5-6, accessed 01/09/2021.

42 E.g. recitals 1 and 31.

43 This also applies to whistleblowers who, to the extent covered by the Directive, disclose business secrets acquired in a work-related context. In such a case, the defendant whistleblower does not have to prove that they acted in defence of the general public interest, as required by Article 5(b) of Directive 2016/943 of 8 June 2016 on the protection of secret know-how and classified commercial information (business secrets) against their unlawful extraction, use and disclosure; see Article 21(7) and recital 98 of the Directive.

44 Article $15(1)(b)(i)$. 
protection in the provisions implementing the Directive conditional on an action in the public interest is unacceptable. At the same time, the Directive indicates a way to relieve signalling systems from reports clearly unrelated to the protection of the public interest. Namely, in accordance with recital 22, reports concerning grievances about interpersonal conflicts between the reporting person and another worker can be channelled to other procedures. We believe it is appropriate to introduce such a regulation to the provisions implementing the Directive. The use of such a model regulation frees the whistleblower and the entities assessing the notification from considerations of the notion of public interest and doubts as to whether the report takes the public interest into account. At the same time, it makes it possible to sift out reports that are clearly not intended to protect the public interest and to extend protection to a broader group of whistleblowers than would be the case if the public interest concept were adopted. It is a simple instrument, easy to understand by the addressees of the law and easy to evaluate by the authorities applying the law, which at the same time has the good effect of not protecting reports obviously made in the private interest. If the solution suggested in recital 22 as described above is not adopted, reports in the purely private interest will enjoy protection under the Directive. However, the protection of whistleblowers motivated by the expectation of personal gain or financial gain should not be excluded or limited. Indeed, such motives do not preclude the disclosure of truthful information concerning an irregularity, the disclosure of which is generally in conformity with the purpose of the Directive as expressed in Article 1.

Some separate remarks are necessary to determine the personal scope of protection of whistleblowers who make a public disclosure. Article 15 of the Directive, which sets out these conditions, makes protection conditional on disclosure where the whistleblower has not received feedback within the required time-limit after making an internal or external report, or where this feedback shows that appropriate follow-up action has not been taken. ${ }^{45}$ Coverage will also be justified without prior internal or external report if the whistleblower has reasonable grounds to believe that the special circumstances indicated in Article 15 (1)(b) have occurred. We are of the opinion, as stated above, that the term "reasonable grounds to believe" refers to the judgment that a reasonable observer in the whistleblower's position would make. It also follows from an interpretation of the above provision in conjunction with Articles 5(7) and 6 of the Directive that the described conditions of protection in the case of public disclosure are of additional nature, which means that in order to obtain protection, a whistleblower making a public disclosure must comply with the previously described conditions set out in these provisions.

The Directive uses a specific solution with regard to anonymous signalling. Namely, it leaves it to the discretion of the Member States whether legal entities and competent authorities are to accept and follow up anonymous reporting. At the same time, even where national law does not accept anonymous reporting, if such reporting is

45 Cf. recital 79. 
accepted or an anonymous public disclosure is made and the whistleblower is identified, they are protected from retaliation. This means that an anonymous whistleblower who has made a public disclosure under the conditions indicated in Article 15(1) (b)(i) and has been identified is protected regardless of whether the Member State accepts anonymous reports through internal and external channels. The Directive also provides that where anonymous reporting is permitted under national law, it should be followed up with due diligence. ${ }^{46}$ It would seem worthwhile to supplement this vague provision with a clear imposition of the obligation on operators of internal and external channels to maintain confidentiality when the identity of anonymous persons is disclosed, and when their identity is ascertainable.

In Article 4(1-3), the Directive indicates a wide range of persons who should be considered whistleblowers. These include both employees and self-employed persons, shareholders, members of corporate bodies, volunteers, etc. This list is illustrative and minimal. Transposition may extend this list, but not close it. Protection should apply to all persons who are reporting persons within the meaning of the Directive and who meet the conditions laid down therein for benefiting from the protection. However, important doubts concern the definition of persons entitled to protection in Articles 4(2) and 4(3). These provisions also recognize as whistleblowers individuals who report breaches of which they become aware after the relationship in which they had with a legal entity has ended, as well as individuals who report breaches concerning information they obtained in the course of recruitment or negotiations that preceded the establishment of a legal relationship with that entity. The English version of the text of the Directive defines this relationship as a "work-based relationship". In contrast, many other language versions, including the languages of the countries surveyed, use the term "employment relationship". This difference is significant because it leads to a vital differentiation between the circle of whistleblowers and the possibilities of reporting breaches. In our opinion, the relationship indicated above cannot be equated with an employment relationship. It refers to all relations connected with the broadly understood work of persons mentioned in Article 4(1) and other persons who report or publicly disclose information on breaches acquired in the context of their work-related activities. Such a conclusion is justified by a systematic interpretation of Article 4(1) as a whole and by the purpose of that provision and of the Directive as a whole, which is to create the widest possible opportunities for reporting breaches in a work-related context. ${ }^{47}$ In view of the above, we believe that the term "work-based relationship" (relationship based on work) should be used in the provisions implementing the directive. This is also the safest solution, because this interpretation is more beneficial to whistleblowers' rights than the use of the term "employment relationship".

46 Article 9(1)(e).

47 The correctness of such an interpretation is also confirmed by the last sentence of recital 39, as well as by the Council of Europe's position explaining the use of the same term; Council of Europe, 2014, p. 20. 
Finally, consideration should be given to certain proposals made in the literature to extend legal protection for whistleblowers beyond the personal scope of the Directive. This applies in particular to persons who only intend or attempt to disclose information and to persons who do not disclose or do not even intend to report but are suspected of having done so or may do so. ${ }^{48}$ The protection of these persons is currently limited to requiring Member States to impose a prohibition on hindering or attempting to hinder reporting and sanctions for breaches of this prohibition. ${ }^{49}$ Such protection does not appear to be sufficient, however, as punishing the offender does not remedy the harm suffered through retaliation. Such protection should be afforded, for example, by expressly providing in national legislation for the general rule that a person suspected of whistleblowing, and intending or attempting to carry out whistleblowing, may not for that reason suffer retaliation in a work-related context. Although even without such an explicit reservation in the law the disclosure of such circumstances in court proceedings should result in the court granting protection in the form of, for example, acknowledging the wrongfulness of the termination of the employment contract or another act of the employer, but this may prove ineffective, for example, in a case for compensation for the termination of a civil law contract, where the reason for the termination may be irrelevant. Stronger protection would be provided by an appropriate application of Chapter VI of the Directive to the above-mentioned groups of persons.

\subsection{Personal scope of indirect protection}

Indirect protection is extended by the Directive to the facilitators, i.e. natural persons who assist the whistleblower in the reporting process, third parties connected with the whistleblower and legal entities which are owned by the whistleblower or are otherwise connected with the whistleblower in a work-related context. Several issues need to be raised in connection with this regulation and in the context of implementation.

The first comes down to the question whether it is permissible to broaden in national legislation the circle of persons covered by indirect protection. A comparison of the way in which the personal scope of direct protection is defined in Article 4(1) and that of indirect protection in Article 4(4) indicates the intention to limit the entities covered by indirect protection to the indicated three groups of persons. Their list, contained in Article 4(4) of the Directive, is not of an open nature. The possibility of extending this protection to other entities would have to be based on an expansive interpretation of Article 25(1), which empowers Member States to adopt provisions more favourable to the rights of whistleblowers. Literalistically,

48 See Transparency International, 2019, pp. 5-6; Transparency International, 2018, pp. 11-13; Council of Europe, 2014, p. 38.

49 Article 23 (1)(a). 
the extension of the personal scope of indirect protection is not the adoption of provisions more favourable "to the rights" of whistleblowers. However, this is, as the wording of Article 25(1) is clarified in recital 104, a measure that is more beneficial to whistleblowers. We believe that the latter interpretation is more justified.

The scope of the term "facilitator" also requires some comment. It is argued that the definition of facilitator in the Directive excludes from protection trade unions as such, i.e. as legal persons and other civil society organizations and their activists. We believe that support and protection for such organizations is needed. However, it should be introduced by a special regulation, other than a directive explicitly aimed at protecting individuals. Employees and activists of organizations other than trade unions, on the other hand, remain outside the personal scope of the Directive due to the fact that they are not acting in a work-related context. Including them as natural persons in the protection against retaliation seems justified. However, this would have to entail an extension of the notion of facilitator also to other natural persons operating outside a work-related context. This is because they may, due to lack of organizational support, be more vulnerable to retaliation than civil society activists. We also believe that protection should be awarded not only to those who assist the whistleblower in making the report, but also to those who help the whistleblower after the report has been made, e.g. by protecting the whistleblower from being exposed or by opposing adverse actions taken against them. In our opinion, persons who disclose information supplementing information about breaches previously disclosed by another person are not facilitators. Such persons should be considered as separate whistleblowers.

\section{Internal reporting channels}

\subsection{Obliged entities}

According to the Directive, internal channels are of fundamental importance..$^{50}$ It is also in the direct interest of the entities in which such channels should be set up that they are established as well as function smoothly and enjoy the trust of whistleblowers - because this gives such organizations the opportunity to not only remove irregularities, but also examine a case internally, without it being brought to the attention of external bodies or gaining publicity.

In principle, taking into account the exceptions under Article 8(4) and Article 8(7) of the EU Whistleblower Protection Directive, reporting channels should be established in private undertakings with at least 50 workers in the broad sense of Article 45 TFEU. The obligation to establish internal reporting channels in smaller undertakings, with more than 20 and fewer than 50 workers, apart from the

50 Article 8(1), recital 47 of the EU Whistleblower Protection Directive. 
above-mentioned exceptions resulting from the Directive, does not seem to be a right solution on account of the significant financial effort needed to set up a channel that meets all requirements, i.e. is autonomous, fully confidential and maintained by specialized and professionally trained staff members as well as enables a prompt and efficient internal investigation. What seems problematic is the ability to keep confidential the identity of the whistleblower within minor organizations. This is why it would appear more beneficial for persons who are employed in such entities to make their reports directly through external channels. ${ }^{51}$

In turn, it seems that in all legal entities in the public sector, irrespective of the number of inhabitants of the administrative unit in which the entity or body operates, internal channels should be established.

In the Directive, entities obliged to set up internal reporting channels are usually referred to as "legal entities" or "organizations". Occasionally, the terms "employer"52 or "undertaking" 53 are used. The occasional use of the latter two terms is understandable, since the entity obliged to establish an internal channel need not be an employer or an undertaking, although it is most often both. ${ }^{54}$

The use of the inclusive term "legal entity" and not the terms "natural person" and "legal person" justifies the thesis that the basis of legal capacity is not a defining criterion for a "legal entity" ${ }^{55}$ The role of "legal entity" and the semantic contexts in which the term, with one exception, ${ }^{56}$ appears in the Directive support the conclusion that it can cover both natural and legal persons, as well as associations of persons or organizational entities having legal capacity, despite the lack of legal personality, such as general partnerships and partnerships under some national laws. It is essential that it is a unit in which, by virtue of its separation and having its own set of workers and collaborators and tasks, there may be breaches for which an internal channel is needed and that it is equipped with the legal powers to respond appropriately to breaches in accordance with the procedures for the operation of such a channel. It is desirable, however, that that entity should be able to take legal responsibility. It is, in fact, as has been pointed out, most often the person who is the "person concerned" by the report or who is the object of the report, whether it concerns an organ or an employee. Therefore, the Directive defines the "person

51 Cf. K. Wygoda, D. Wasiak, Poufność informacji o sygnaliście jako ultima ratio systemu compliance (Confidentiality of information about the whistleblower as the ultima ratio of the compliance system), [in:] B. Baran, M. Ożóg (eds.), Ochrona sygnalistów. Regulacje dotyczqce osób zgłaszających nieprawidłowości (Whistleblower Protection. Regulations Concerning Persons Reporting Irregularities), Wolters Kluwer, Warsaw 2021, p. 111.

52 Recital 47.

53 E.g. Article 4(1)(c).

54 See Z. Hajn in this monograph.

55 Similarly for example, in recital 8 and Article 2(c) of the Directive 2009/52/EC of the European Parliament and of the Council of 18 June 2009 providing for minimum standards on sanctions and measures against employers of illegally staying third-country nationals.

56 See Article 4(4)(c). 
concerned" as a natural or legal person who is referred to in the report or public disclosure as a person to whom the breach is attributed or with whom that person (i.e. person to whom the breach is attributed) is associated. The person identified as the infringer therefore ought to be a natural or legal person, as this guarantees the capacity to bear legal liability, in particular civil liability for damages. As seems appropriate, entities having legal capacity equivalent to legal personality, such as certain companies without legal personality, should be put on an equal footing. However, the lack of such capacity should not disqualify an entity from being a legal entity within the meaning of the Directive. In such a case, the law should ensure that legal liability is borne by the natural or legal persons who "stand behind" such an entity, such as a company behind its branch. ${ }^{57}$

The specificity of the concept of "legal entity" in the Directive is further revealed in relation to groups of undertakings. Internal reporting procedures should enable legal entities in the private sector to receive and investigate in full confidentiality reports by the workers of the entity and of its subsidiaries or affiliates ("the group"), but also, to any extent possible, by any of the group's agents and suppliers and by any persons who acquire information through their work-related activities with the entity and the group..$^{58}$ The establishment of an internal channel at group level does not prevent it from also being set up at the level of the individual companies in the group. Moreover, it is compulsory for entities with at least 50 employees.

It should be added that a whistleblower may make reports through several internal channels administered by legal entities with which they have a working relationship.

A reporting system at the level of a group's central management, maintained not only in the official language of the state in which the group is registered, but also in other languages which are appropriate for a given group, would be especially useful in the case of reports concerning breaches involving the group's supranational activity, e.g. violations of human rights, violations of foreign law or complaints of irregularities in the operation of controlled companies affecting interests of the whole group.

\subsection{The role of worker representative bodies}

An internal reporting channel should be consulted or agreed upon, depending on the provisions and practice in force in a given country, with trade unions or other worker representatives. ${ }^{59}$

57 This problem may concern countries such as Poland, where the status of employer is also granted to entities without legal personality, if they have the so-called capacity to hire employees. This applies in particular to governmental organizational units, local government units and separate internal units of private sector companies.

58 Recital 55.

59 V. Abazi, Guide. Internal Whistleblowing Channels and the Role of Trade Unions, Eurocadres, 2021, https://www.eurocadres.eu/publications/guide-internal-whistleblowing-channels-andthe-role-of-trade-unions/, accessed 01/09/2021. 
Furthermore, trade unions or workers' councils should have right to information and consultation with regard to the number of reports and the results of investigations in matters covered by the scope of these bodies' activities, such as in particular breaches of provisions concerning occupational health and safety, anti-discrimination, mobbing or violence in the workplace. Reports of labour law breaches directly to trade unions should not be treated as public reports. Moreover, the content of recital 45 of the EU Whistleblower Protection Directive must be criticized, as it places on an equal level the status of reports made through online platforms or social media and reports directed to trade unions. Situations of public disclosures taking place for example at trade union meetings should be distinguished from reporting to trade union officials or other employee representatives in full confidentiality where a whistleblower counts on their support. The attention should be drawn to a fact, that especially in the context of reporting breaches of labour law, trade unions are natural allies of workplace whistleblowers who could give them advice, support or inform about the appropriate ways or methods of conduct. ${ }^{60}$ For this reason trade union representatives or other employee representatives are qualified as facilitators, ${ }^{61}$ granted protection against retaliation and bound by the obligation of confidentiality. ${ }^{62}$

\subsection{Necessary elements of the design of internal channels}

When establishing an internal reporting channel, the relevant entity should in a clear and accessible manner specify the material scope of the reports, the reporting procedure, the group of persons entitled to use the channel as well as the follow-up. The relevant information should be easily accessible, including, also to persons other than workers who are in contact with the entity in the context of their work-related activities, such as service-providers, distributors, suppliers and business partners if a given channel is open to reporting from these persons. ${ }^{63}$ The access to the internal reporting channel should be given not only to workers, but also to other persons who cooperate with the entity in a work-related context. ${ }^{64}$

It should be explicitly mentioned in the information about the internal channel that there is no obligation to use said, prior to making a report through an external channel. ${ }^{65}$

60 See also V. Abazi, The European Union Whistleblower Directive: A 'Game Changer' for Whistleblowing Protection?, Industrial Law Journal, Volume 49, Issue 4, December 2020.

61 See recital 41 of the EU Whistleblower Protection Directive.

62 See Article 5(8) of the EU Whistleblower Protection Directive. On this subject cf. G. Bargain in this monograph.

63 Cf. recital 59 of the EU Whistleblower Protection Directive.

64 The option to enable other persons than workers to report within internal channels is provided for in Article 8(2) second sentence of the EU Whistleblower Protection Directive.

65 About the autonomy of a whistleblower in this context see W. Vandekerckhove, Is It Freedom? The Coming About of the EU Directive on Whistleblower Protection, Journal of Business Ethics, https://doi.org/10.1007/s10551-021-04771-x, accessed 01/09/2021. 
A clear and easily accessible information should be further provided, pursuant to Article 9(1)g of the Directive, regarding the procedures for reporting externally to competent authorities. In addition, the body that operates the internal channel should make it clear that when the whistleblower is in work-related relations with several legal entities, they can make the report to the organization related to the acquisition of information.

An internal channel should be autonomous in relation to other communication channels within the organization and be operated by a constant, limited number of staff members who have been professionally trained in the operation of such a channel and have legal expertise that enables them to assess the character of such a report as well as personal data protection knowledge. Furthermore, they should have relevant authorizations concerning personal data processing.

When an organization decides to cooperate with an external entity, it is recommended that it is an entity that provides services reserved to regulated professions, such as attorneys, attorneys-at-law, auditors or tax advisors, whose representatives are bound by professional privilege and guarantee confidentiality to the persons who make a report through them. ${ }^{66}$

An internal channel should render it possible to make reports not only orally or traditionally, in writing, but also electronically, so as to protect the identity of the reporting person with the use of modern technology ${ }^{67}$ In this context it is worth noticing that a new norm ISO 37002 Whistleblowing Management System-Guidelines ${ }^{68}$ was elaborated by International Organisation for Standardisation, according to which internal reporting channels should be founded on three principles: confidentiality, impartiality and whistleblower protection.

The time limit for acknowledging the receipt of the report - seven days - is laid down explicitly in Article 9(1)(b) of the EU Whistleblower Protection Directive. The timeframe to provide feedback should not exceed three months (Article 9(1)(f)). Still, if according to the report a criminal offence has been committed or planned, following the necessary assessment of the accuracy of the allegations as part of internal investigation, in our opinion the matter should be immediately referred to the relevant external channel. The internal channels are not appropriate to deal with such matters. In matters other than criminal offences, referring a report to a different channel should be subject to the whistleblower's consent, due to the fact that whistleblowers might have reasons to choose a specific channel. ${ }^{69}$

66 Cf. K. Wygoda, D. Wasiak, Poufność informacji o sygnaliście jako ultima ratio systemu compliance (Confidentiality of information about the whistleblower as the ultima ratio of the compliance system), [in:] B. Baran, M. Ożóg (eds.), Ochrona sygnalistów. Regulacje dotyczace osób zgłaszających nieprawidłowości (Whistleblower Protection. Regulations Concerning Persons Reporting Irregularities), op. cit., p. 111.

67 Cf. E. Bielak-Jomaa in this monograph.

68 Management System-Guidelines, https:/www.iso.org/standard/65035.html, accessed 01/09/2021.

69 See TI, Transparency International, Building on the EU Directive for Whistleblowing Protection. Analysis and Recommendations, Position Paper 1/2019, p. 10. 


\section{External reporting channels}

\subsection{The role of the central authority for whistleblowers}

None of the national legislations analysed under the WhistlePro Grant provides for one external body that would receive and examine reports of breaches of the law. As a matter of fact, such a solution would not be optimal due to the varied subjects of the reports, which concern matters related to all sorts of areas of the state's activity.

Thanks to a multitude of external channels, ${ }^{70}$ a report may be examined by the authority which is most competent in a given matter. On the other hand, however, it creates uncertainty in potential whistleblowers as to the proper external channel which they should use to make the report, and often discourages them from whistleblowing. A method where whistleblowers are directed to various external channels by an institution operating at the central level is used in France and in Hungary. In both these countries, this role is played by the constitutional body competent for the protection of human rights. In France it is the Défenseur des droits (Defender of Rights), and in Hungary - the Commissioner for Fundamental Rights. In Slovakia, an Office for the Protection of Whistleblowers is currently being established. It is going to have broad competences including, among others, the right to suspend, by means of an administrative decision, labour acts performed by the employer against the whistleblower.

It should be advocated that in those countries which have not yet established a central authority for whistleblowers, such an authority be established. Such an authority would ensure, among others, that reports are directed to appropriate external channels by possibly setting up one protected electronic channel as for example in Hungary within the Office of the Commissioner for Fundamental Rights. ${ }^{71}$ It would not, however, act as the exclusive external reporting channel. Furthermore, its role would be to inform about the appropriate external channels and to advise potential and current whistleblowers about their rights and means of protection against retaliation. ${ }^{72}$ It is recommended that the authorities designated to perform the above functions join the already existing Network of European Integrity and Whistleblowing Authorities based in the Hague. It is highly desirable that the central

70 As follows from the information provided by the Office of the Hungarian Commissioner for Fundamental Rights, the Commissioner remains in contact with 280 public authorities via an electronic channel for external reports that it maintains. See A. Gulyas, Z. Baksa, [in:] I. Miernicka, A. Pietras, D. Skupień (eds.), Workplace Whistleblower Protection in the V4 Countries, France and Slovenia. Current Regulations and Proposed Changes. Book of Abstracts. International Scientific Conference Organised Online. Department of European, International and Collective Labour Law. Faculty of Law and Administration, University of Lodz, $15^{\text {th }}$ June 2021, Lodz University Press, Lodz 2021, p. 16.

71 See chapter 2 of Act CLXV of 2013.

72 Compare Article 20(3) of the EU Whistleblower Protection Directive. 
bodies responsible for receiving reports cooperate. Whistleblowing may, after all, concern breaches of foreign or Union law, and the report should be directed to the appropriate whistleblowing authority in another country or to the competent Union body. Albeit it exceeds the scope of the present analysis, it should further be advocated that a central authority for whistleblowers be set up at the level of the European Union. This body would direct potential whistleblowers to the appropriate Union bodies and institutions. At present, such duty to inform about the above-mentioned bodies and institutions falls upon legal entities responsible for the organisation of procedures for internal reporting (Article 9(1)(g) of the directive) what may exceed their competencies.

Projects aiming at entrusting the competences of a national office for whistleblowers to ministry departments or other institutions within government administration should be assessed negatively. Such a role should be performed by an institution with a legislative mandate that is autonomous from the executive power. As it clearly results both from Article 20(3) of the Directive as well as from its recital 89 the administrative authority designed to support whistleblowers should be 'independent'.

In the event that the central authority competent for whistleblowing does not exist and it is not planned to establish such an authority due to e.g. significant costs, a creation of a separate entity for whistleblowing within an institution enshrined in the constitution, such as the office of the national ombudsman, is recommended. An example could be the Department for Whistleblower Protection and Customer Services at the Office of the Commissioner for Fundamental Rights in Hungary.

\subsection{Organisation of the external channels}

Reporting channels maintained by "external" institutions should be autonomous and independent in relation to other reporting channels operated by that institution. As follows from the past experience of the Hungarian Commissioner for Fundamental Rights, the boundary between internal channels and external channels in authorities or institutions is often blurred. ${ }^{73}$ Such a situation should be avoided in the future.

The external reporting channels should guarantee the whistleblower the full confidentiality, the protection of their personal data and of a person whom the report concerns as well as ensure an efficient handling of the report. Depending on the nature of the case, anonymity of the report should be allowed in most serious instances, where the whistleblower or their relatives are in danger of harm to health or life. Currently, certain sector-specific provisions permit anonymous reporting.

73 See A. Gulyas, Z. Baksa, [in:] I. Miernicka, A. Pietras, D. Skupień (eds.), Workplace Whistleblower Protection in the V4 Countries, France and Slovenia. Current Regulations and Proposed Changes. Book of Abstracts. International Scientific Conference Organised Online. Department of European, International and Collective Labour Law. Faculty of Law and Administration, University of Lodz, $15^{\text {th }}$ June 2021, op. cit., p. 16. 
It seems that, also in those countries which manifest scepticism as to the admissibility of anonymous reports at least a reservation should be made in the general provisions transposing the Directive that such reports have to be examined and the factual circumstances mentioned in the report should be investigated. Another solution would be, in case the central authority for whistleblowing operates the protected electronic channel, that whistleblowers making a public interest disclosure to this protected channel may request that their personal data are made available only to this central authority and the disclosure is transmitted in a anonymised format to a competent external body. ${ }^{74}$

When a report is made non-anonymously, it is necessary to ensure, by analogy to the case of internal channels, full confidentiality of the whistleblower's personal data, taking into account the possibilities offered by modern technologies. An example could be the electronic system for reporting breaches to the Hungarian Commissioner for Fundamental Rights. ${ }^{75}$ Other methods of ensuring confidentiality are for example a dedicated telephone line or a use of double envelopes.

A vital element of an external reporting system that is expected to be safe for the whistleblower is to designate for its operation properly trained staff members - specialists of good repute and high professional ethics.

It does not seem advisable that external channels enable a selection of reports according to the level or priority, even though such an option is allowed by Article 11(3) of the Directive. However, Member States could consider introducing the solution provided for in Article 11(4) of the EU Whistleblower Protection Directive, under which it is possible not to follow up on repetitive reports that contain no new information in comparison to the previous reports. ${ }^{76}$

\subsection{Financial incentives}

The issue of financial incentives for whistleblowers is controversial. The competence to grant remuneration has been vested e.g. in the Slovak Office for Whistleblower Protection, ${ }^{77}$ albeit such decisions are arbitrary and not actionable. Moreover, the whistleblower may not claim any remuneration. The award of remuneration in Slovakia depends on a number of factors, e.g. whether the report resulted in the detection and punishment of the perpetrator in criminal or administrative proceedings, what the extent of the whistleblower's participation in clarifying serious breaches and identifying the perpetrator was, whether the whistleblower lost any earnings as a result of making the report and what the size of the seized or returned property was.

74 Compare $\S 6$ of Hungarian Act CLXV of 2013. See also M. Terracol, A Best Practice Guide for Whistleblowing Legislation, Transparency International, 2018, p. 20, https://www.transparency. org/en/publications/best-practice-guide-for-whistleblowing-legislation, accessed 01/09/2021.

75 Cf. Chapter 2 of the Hungarian Act CLXV of 2013.

76 Cf. Section 2/A5 of the Hungarian Act CLXV of 2013.

77 Cf. Section 9 of the Slovak Act of 2019. 
The issue of financial incentives for whistleblowers should be left to national legislation. Above all, fight against certain types of breaches may be a political priority in a specific period of a state's functioning. Such priorities could be in particular fight against corruption, terrorism or organized crime. Therefore, state authorities should be free to guarantee financial rewards or a certain percentage of the recovered property. Still, such solutions require a great deal of caution so that whistleblowing, which is an act of social sensitivity, does not morph into commercial activity - into remunerated informing, which has negative historical connotations in Central and Eastern Europe.

\section{Public disclosures}

Under Article 15 of the EU Whistleblower Protection Directive, a public disclosure is a last resort. On the one hand, a whistleblower should have reasonable grounds to believe that the breach may constitute an imminent or manifest danger to the public interest, for instance where there is an emergency situation or a risk of irreversible damage, or, in the case of external reporting, that there is a risk of retaliation or there is a low prospect of the breach being effectively addressed on account of the particular circumstances of the case, such as those where evidence may be concealed or destroyed or where an authority may be in collusion with the perpetrator of the breach or involved in the breach.

In order to qualify for protection in case of the public disclosure, the whistleblower should first make an internal and an external report or directly an external report. A public disclosure may be made when no appropriate action was taken in response to the report. In that context, it should be proposed that national legislations that transpose the EU Whistleblower Protection Directive specify the meaning of the expression "appropriate action", whose lack opens the door to public disclosures. Recital 79 of the Directive does not give a sufficient explanation of this concept.

Furthermore, the requirements for protection in case of a public disclosure under EU Whistleblower Protection Directive vary from conditions elaborated in the case law of the European Court of Human Rights. ${ }^{78}$ Especially, there is uncertainty concerning the meaning of such concepts used in Article 15(1)b of the Directive as an 'imminent or manifest danger to the public interest', an 'emergency situation', a 'risk of irreversible damage' or a 'low prospect of the breach being effectively addressed'. This uncertainty may have negative consequences for the protection of a whistleblower against retaliation. Therefore, it is proposed that temporary safeguards in case of public disclosure are introduced into national legislations, in order to prevent any immediate action by the employer before the circumstances are clarified. ${ }^{79}$

78 Cf. M. Górski in the present monograph.

79 Cf. D. Senčur Peček in the present monograph. 


\section{Protection against retaliation}

\subsection{General remarks}

The protection of whistleblowers against retaliation by the entity to which a report or public disclosure relates is of key importance to achieving the objectives of the Directive as well as the objectives of the national implementing provisions. The problems related to the implementation of the protection provisions of the Directive covered in this section relate to two groups of issues, i.e. the prohibition of retaliation and the measures to protect against retaliation. For the sake of full clarity of further comments, let us recall that, according to the findings set out above in point 4 , a whistleblower is protected, including protection from retaliation, if: they are a natural person, they have reported or publicly disclosed information about breaches, they obtained the information in a context related to their work, they had reasonable grounds to believe that the information was true at the time of reporting and falls within the scope of the Directive or possibly legal provisions extending the material scope of reporting breaches, they not been registered as a paid whistleblower and their report is not in the nature of a complaint made solely in their private interest related to a conflict with another person. These conditions derive from Articles 5(7) and 6 of the Directive.

\subsection{Prohibition of retaliation}

Article 19 of the Directive requires Member States, in implementing its provisions, to prohibit all forms of retaliation as well as threats and attempts of such action against whistleblowers and persons associated with them, as defined in Article 4 of the Directive. Encouraging or recommending retaliation by an employer or other duly placed persons should also be considered as retaliation (recital 87). However, the prohibition applies to the acts of this kind themselves and is in the nature of an obligation to refrain from the conduct indicated. We believe that an important strengthening of the protection at issue would be to complement this prohibition in national legislation by imposing on the employer or other legal entity an obligation to prevent retaliatory behaviour within the organization it manages. Such a provision would also have a preventive function.

The statement in Article 5(11) that retaliation is any direct or indirect conduct occurring in a work-related context means that the retaliation must be linked to the whistleblower's work activities. At the same time, however, it should be borne in mind that action against whistleblowers can also be taken outside the work-related context, e.g. through defamation actions (recital 97). Retaliation is any conduct that causes or is likely to cause harm (recital 44). It is thus any intentional wrong inflicted on the whistleblower or a person associated with him/her within the meaning of 
Article 4(4). The implementation of Article 19 must therefore consist first in establishing a general prohibition of all retaliation. A good model for the general form of the prohibition is $\$ 11$ of the Hungarian whistleblowing law, ${ }^{80}$ which considers as unlawful retaliation any action taken as a result of disclosure that may cause adverse consequences for the whistleblower, even if it would otherwise be lawful. It is then necessary to provide a list of examples of such forms, modelled in particular on Article 19(a-o) of the Directive. This list should also include examples of actions directed against persons whose work-based relationship is not an employment relationship, such as volunteers, suppliers of goods or contractors.

\subsection{Measures for protection against retaliation}

In order to protect whistleblowers from and in the case of retaliation by the employer (other legal entity), the Directive provides an extensive set of protection measures in Article 21. Member States should ensure that these measures or other rights set out in the Directive cannot be waived or limited by contract, specific policy, form or conditions of employment of the employee, or by pre-dispute arbitration agreement (Article 24).

However, in order to benefit from a substantial part of these measures, the Directive stipulates an additional condition, not provided for in Article 6, which is that the whistleblower must have reasonable grounds to believe that the notification or public disclosure is necessary to disclose the breach in accordance with the Directive. This condition refers to protection from criminal, civil, administrative or employment liability for breach of restrictions on disclosure arising, for example, from loyalty clauses in contracts, confidentiality agreements, etc. (Article 21(2)). In contrast, in legal proceedings, including for defamation, breach of copyright, breach of secrecy, breach of data protection rules, disclosure of trade secrets, or compensation claims based on private, public, or collective labour law, the condition concerns the protection against liability arising from making a report or public disclosure and the possibility of exercising the right to discontinue the proceedings (Article 21(7)). As stated in recital 97, in this type of proceedings, the burden to prove that the whistleblower does not comply with the conditions laid down in the Directive should be on the person requesting the proceedings. In our opinion, it should be assumed that the term "reasonable grounds to believe" refers to the judgement that a reasonable observer in the whistleblower's position, i.e. for instance occupying a comparable position and having comparable knowledge and experience, would make. However, assessing whether reporting or public disclosure is necessary to disclose a breach under the Directive may be difficult in a number of cases and perceived as risky by potential whistleblowers. Fear of taking such risks may also lead to abandonment

80 Act CLXV of 2013 on complaints and public interest disclosures, http://corruptionprevention. gov.hu/download/7/a2/90000/KIM\%20555_2013-4.pdf; accessed 01/09/2021. 
of the reporting. For these reasons, we believe that Member States should consider whether introducing this condition of protection is necessary.

There is some ambiguity regarding the Directive's rules on the burden of proof in proceedings concerning damage caused by retaliation against the reporting person. In such a case, according to Article 21(5), if the person establishes that they made a report or public disclosure and suffered harm, the person who took the measures which caused the detriment shall bear the burden of proving that they did so for duly justified reasons. Thus, it follows from a literal reading of the quoted provision that the perpetrator of the retaliation can justify it and win the lawsuit if shows that there was some legitimate basis for the measure taken, such as a reason justifying termination. At the same time, recital 93 explains that once the whistleblower has made a prima facie proof, the burden of proof should be shifted to the person who committed the damaging action, and that person should then demonstrate that the action taken was in no way related to the notification or public disclosure. It should therefore be requested that the provisions implementing the Directive with regard to the burden of proof take account of the interpretation of Article 21(5) set out in recital $93 .{ }^{81} \mathrm{It}$ should be added that, in our opinion, the term "a detriment suffered by the reporting person" used in Article 21(5) should be understood broadly as any kind of negative effects or disadvantages resulting from the form of retaliation used. It may therefore include pecuniary damage in the form of lost earnings or income, as well as deprivation of promotion, failure to qualify for training, deterioration of health or suffering.

Another type of postulate is related to the implementation of the provisions related to the so-called "remedies" provided for in Article 21(6) and (8) of the Directive. These are, as it ought to be understood, various legal remedies of procedural nature in the form of the possibility to file applications and bring lawsuits before courts and other bodies applying the law (Article 21(6)), and of substantive nature, in the form of claims for which whistleblowers and other persons mentioned in Article 4 of the Directive (Article 21(8)) may expect satisfaction, in order to nullify or minimize the effects of retaliation. This may be, depending on the situation, compensation covering actual loss and lost profits, restoration, transfer to an equivalent position, payment of retraining costs, payment of medical expenses, compensation for non-material damage, restoration of a deprived promotion, etc. All these possibilities are covered by the laconic content of the provisions mentioned above. However, it is desirable that, in the provisions implementing the Directive, the wording "shall have access to remedial measures in accordance with law" is not simply used with no further clarification but supplemented by an illustrative list of remedies showing the variety of possibilities for redressing the effects of retaliation.

A few words should also be devoted to a special type of remedial measures, which are the so-called interim relief measures (Article 21(6)). Their purpose is to prevent the claimant or plaintiff from actually losing the case before it is heard, such as in the event of termination of the employment relationship due to expiry of the notice

81 Cf. also Transparency International (2019), p. 7. 
period before the case is heard by the court. There are two aspects to this issue. The first is to ensure that courts and other authorities applying the law are able to apply sufficiently broad and flexible measures to secure the claim, such as the possibility to suspend the period of notice of termination of an employment contract. The second is to ensure a quick response, e.g. by implementing special judicial or administrative procedures of short duration to secure whistleblower claims. ${ }^{82}$ In their absence, whistleblowers will be left with the "usual" remedial measures of mitigating the damage caused, which may already be irreversible.

\section{Measures of support}

Article 20 of the EU Whistleblower Protection Directive divides measures of support in particular into three categories, namely: comprehensive and independent information and advice on procedures and remedies available, on protection against retaliation, and on the rights of the person concerned; effective assistance from competent authorities and legal aid. It encompasses thus a whole range of measures that increase the whistleblowers' sense of security, both in the context of protection of their employment relationship and of protecting them against adverse actions, which in extreme cases can pose a threat to the health or life of the whistleblower or the persons associated with them.

In terms of support measures, it should be advocated that a whistleblower should be exempted from legal fees and be entitled to legal aid ex officio in labour law cases and in actions for damages or other proceedings in which they are sued in connection with a previous act of whistleblowing, such as proceedings concerning alleged infringements of personal data, copyright or business secrets, regardless of the whistleblower's financial situation. An important aspect in this regard would be for the relevant external body that handles the report to certify that a report was made and thus confirm the whistleblower's status in the proceedings.

When a person is still planning to submit a report, the state should ensure them advice free of charge provided by specialists through the national authority for whistleblowers. Furthermore, the establishment of contact points in individual regions/ provinces of a state should be considered. Since more drastic retaliatory actions are imaginable in the case of reports about crimes and other serious breaches of law, an efficient witness protection system should be introduced. It would also be advisable to introduce the right to psychological support in the framework of judicial proceedings. ${ }^{83}$

82 E.g. in Slovakia, a special administrative body has been established with the power to secure the claims of whistleblowers; see: Act from 30 January 2019 No. 54/2019 Coll. on the protection of whistleblowers of anti-social activities and on change and amendment of some laws, Article 7.

83 Compare Article 20(2) of the EU Whistleblower Protection Directive. 


\section{Whistleblowing and the duty of confidentiality}

The duty of loyalty to the employer is one of the fundamental worker duties. Disclosing a trade secret may result in both civil and criminal liability of the whistleblower in relation to the employer or the entity with which they cooperate. It should be advocated that the principle of reversed burden of proof be applied in proceedings for damages in connection with the alleged disclosure of trade secrets by the whistleblower. According to recital 97 of the EU Whistleblower Protection Directive, reporting persons should be able to rely on having reported breaches or made a public disclosure in accordance with this Directive as a defence, provided that the information reported or publicly disclosed was necessary to reveal the breach. In such cases, the person initiating the proceedings should carry the burden of proving that the reporting person does not meet the conditions laid down by this Directive.

In the light of Article 21(7) of the EU Whistleblower Protection Directive, where a person reports or publicly discloses information on breaches falling within the scope of this Directive, and that information includes trade secrets, and where that person meets the conditions of this Directive, such reporting or public disclosure shall be considered lawful under the conditions of Article 3(2) of the Directive (EU) 2016/943. ${ }^{84}$ It should be recommended that reporting or public disclosure of other breaches of law than these enumerated within the EU Whistleblower Protection Directive shall be considered lawful according to national transposition acts.

Pursuant to Article 3(3)(a) of the EU Whistleblower Protection Directive, the Directive does not affect the application of Union law or national law relating to the protection of classified information. Nevertheless, it seems that the possibility to report breaches of law that involve the disclosure of classified information should be guaranteed in the area of public security, as well. It is important to share Transparency International's view that an appropriate institution that would handle reports in a manner which guarantees full confidentiality should be set up for this purpose. ${ }^{85}$

A pivotal matter is the possibility to report breaches through representatives of the legal or the medical profession as well as other professions whose representatives have the duty to keep professional secrecy. Even though, pursuant to Article 3(3) (b), the EU Whistleblower Protection Directive does not apply to matters involving the protection of legal and medical professional privilege, it appears advisable that national legislation clearly specify the scope of matters which may be reported by

84 Directive (EU) 2016/943 of the European Parliament and of the Council of 8 June 2016 on the protection of undisclosed know-how and business information (trade secrets) against their unlawful acquisition, use and disclosure. About weaknesses of the EU Trade Secrets Directive see V. Abazi, Trade secrets and whistleblower protection in the European Union, European Papers - European Forum, Volume 1, Issue 3, October 2016, https://www.europeanpapers.eu/fr/ europeanforum/trade-secrets-and-whistleblower-protection-in-the-eu, accessed 01/09/2021.

85 See Transparency International, Building on the EU Directive for Whistleblowing Protection. Analysis and Recommendations, Position Paper 1/2019, p. 3. 
representatives of professions subject to the duty of professional secrecy and that, in the event of a disclosure, the whistleblower be not liable to disciplinary measures and qualify for protection as a reporting person.

\section{Criminal penalties}

A worker who has no possibility to make an anonymous report exposes themselves to retaliation in the event that their personal data are disclosed. For this reason, dissuasive criminal sanctions should be available against legal or natural persons who are responsible for revealing the data of the whistleblower or for a leak of such data from an external or internal reporting channel or who hinder or attempt to hinder whistleblowing. The French law Loi Sapin 2, which introduces in Article 9(II) the threat of two years of imprisonment and the fine of 30000 EUR for individuals who reveal the identity of a whistleblower, of persons covered by the report or any elements of the gathered information as well as in Article 13(I), the threat of one year of imprisonment and the fine of 15000 EUR for persons who hinder the disclosure, ${ }^{86}$ should be viewed positively. With regard to legal entities, in turn, financial penalties contingent on the size of the undertaking and its annual turnover would be suitable.

It should be underlined that the status of a whistleblower should be awarded exclusively to persons who have reasonable grounds to believe that the facts they present as evidence of a breach of law are true.

If the entity that is falsely alleged of breaching the law proves that the reporting person acted in bad faith, a fine should be imposed on the person who abuses the whistleblower status. Another solution could be criminal liability for potential defamation in connection with a public disclosure. In this respect, the abolition of the penalty of imprisonment, as recommended by the Council of Europe, should be advocated. ${ }^{87}$

\section{Conclusion}

In developing legislative recommendations under the WhistlePro Grant for the Visegrad Group countries, France and Slovenia, we were guided by the objective that future regulations should increase the whistleblower's sense of security against disclosure of identity, provide protection for the whistleblower's employment and other business relationships, and eliminate uncertainty about the institution competent to receive the report. It is essential that protection be provided also in the

86 Cf. G. Bargain in this monograph.

87 See the Council of Europe Resolution 1577 (2007), entitled "Towards decriminalisation of defamation". 
event of a public disclosure. A clear definition of the conditions for using the option of public disclosure serves this purpose.

Undoubtedly, the introduction of measures for the protection of whistleblowers in order to transpose the EU Whistleblower Protection Directive, and sometimes even introduce provisions that go beyond its scope, will be a financial burden for the state and entities on which the Directive imposes obligations. It appears, however, that this burden will be worthwhile. With the help of appropriate social and educational campaigns carried out with the participation of NGOs, people who notice negative phenomena in the organization for or with which they work should be encouraged to report these breaches through appropriate channels. In turn, providing effective protection for whistleblowers and introducing severe sanctions for impeding reports and retaliatory actions should discourage potential offenders from committing breaches - a development which will undoubtedly benefit the society throughout the European Union.

\section{Bibliography}

Abazi V., Guide. Internal Whistleblowing Channels and the Role of Trade Unions, Eurocadres, 2021, https://www.eurocadres.eu/publications/guide-internal-whistleblowing-channelsand-the-role-of-trade-unions/, accessed 01/09/2021.

Abazi V., The European Union Whistleblower Directive: A 'Game Changer' for Whistleblowing Protection?, Industrial Law Journal, Volume 49, Issue 4, December 2020.

Abazi V., Trade secrets and whistleblower protection in the European Union, European Papers - European Forum, Volume 1, Issue 3, October 2016, https://www.europeanpapers. $\mathrm{eu} / \mathrm{fr} /$ europeanforum/trade-secrets-and-whistleblower-protection-in-the-eu, accessed 01/09/2021.

Adam P., À propos de la protection générale des lanceurs d'alerte dans l'entreprise privée (Commentaire de la loi dite « Sapin II » du 9 décembre 2016), Revue de jurisprudence sociale, $5 / 2017$.

Banisar D., Whistleblowing: International Standards and Developments in I. Sandoval (ed.) Corruption and Transparency: Debating the Frontiers Between State, Market and Society," World Bank-Institute for Social Research, UNAM, Washington, D.C, 2011, https://ssrn. com/abstract=1753180, p. 5-6, accessed 01/09/2021.

Bolesta Ł., In Search of a Model for the Legal Protection of a Whistleblower in the Workplace in Poland, Peter Lang, Berlin 2020.

European Network of National Human Rights Institutions, State of the Rule of Law in the European Union, Reports of National Human Rights Institutions, 2021, https://ennhri. org/news-and-blog/ennhri-publishes-its-second-annual-report-on-the-state-of-therule-of-law-in-europe/, accessed 01/09/2021.

Łaga M., Unormowania dotyczace sygnalizacji - wzmacnianie demokracji w miejscu pracy (Regulations concerning whistleblowing - strengthening democracy in the workplace) [in:] Z. Hajn, M. Kurzynoga (eds.), Demokracja w zakładzie pracy. Zagadnienia prawne (Democracy in the workplace. Legal aspects), Wolters Kluwer, Warsaw 2017. 
Makowski G., Waszak M., Gnębieni, podziwiani i... zasługujacy na ochronę. Polacy o sygnalistach. Raport z badania opinii publicznej (Oppressed, admired and... deserving protection. Poles about whistleblowers. A report from the public opinion poll), Batory Foundation and Forum Idei, Warsaw 2019, https://www.sygnalista.pl/wp-content/uploads/2019/06/ Internet_Raport_sygnalisci_12-06.pdf, accessed 01/09/2021.

Maśnicki J., Metody transpozycji dyrektyw (Methods of directives' transposition), Europejski Przegląd Sądowy, 2017, No. 8.

Mičudová T., Zákon o oznamovaní protispoločenskej činnosti. Komentár (Act on reporting anti-social activities. Commentary), Wolters Kluwer, Bratislava 2016.

Miernicka I., Pietras A., Skupień D. (eds.), Workplace Whistleblower Protection in the V4 Countries, France and Slovenia. Current Regulations and Proposed Changes. Book of Abstracts. International Scientific Conference Organised Online. Department of European, International and Collective Labour Law. Faculty of Law and Administration, University of Lodz, 15 $5^{\text {th }}$ June 2021, Lodz University Press, Lodz 2021.

Nabernik A., Preden prijavim goljufijo, želim vedeti, kakšno zaščito bom dobil (Before I report fraud, I want to know what protection I will get), Pravna praksa, 33/2019.

Olšovská A., Hrušovská V., Whistleblowing na pracovisku - právna úprava, teória a prax na Slovensku - Whistleblowing at the workplace - legislation, theory and practice in Slovakia, [in:] J. Pichrt (ed.), Whistleblowing, Wolters Kluwer ČR, Prague 2013.

Pichrt J., Morávek J., Whistleblowing: National Report for the Czech Republic, [in:] G. Thüsing G., Forst G. (eds.), Whistleblowing - A Comparative Study, Springer, Cham 2016.

J. Morávek, [in:] J. Pichrt et al., Zákon o státni službě, Komentár (Civil Service Act, Commentary), $1^{\text {st }}$ ed., Wolters Kluwer, Prague 2015.

Prechal S., Directives in EC Law, Oxford University Press, Oxford 2005.

Rommel A., Ochrona sygnalistów we francuskim systemie prawnym (Whistleblower Protection in the French Legal System), [in:] B. Baran, M. Ożóg (eds.), Ochrona sygnalistów. Regulacje dotyczące osób zgłaszających nieprawidłowości (Whistleblower Protection. Regulations Concerning Persons Reporting Irregularities), Wolters Kluwer, Warsaw 2021.

Sedlar A., Zgodovinska prelomnica pri zaščiti žvižgačev v EU (A historic turning point for whistleblower protection in the EU), Pravna praksa, 2019/13.

Senčur-Peček D., Protection of Persons Reporting Corruption and Other Whistleblowers in the Republic of Slovenia, [in:] G. Thüsing G. Forst (eds.), Whistleblowing - A Comparative Study, Springer, Cham 2016.

Senčur-Peček D., Delovnopravno varstvo žvižgačev (Labour law protection for whistleblowers), Delavci in delodajalci, 2-3/2015.

Skupień D., The legal protection of whistleblowers in Poland, [in:] B. Lewaszkiewicz-Petrykowska (ed.), Rapports polonais, XIX Congrès international de droit comparé, Vienne, 20-26 VII 2014,, Lodz University Press, Lodz 2014.

Skupień D., Whistleblowing in Poland According to Legislation and Case Law, [in:] G. Thüsing, G., Forst (eds.): Whistleblowing - A Comparative Study, Springer, Cham 2016.

Szewczyk H., Whistleblowing. Zgłaszanie nieprawidłowości w stosunkach zatrudnienia (Whistleblowing, Disclosing irregularities in employment relationships), Scholar, Warsaw 2020.

Terracol M., A Best Practice Guide for Whistleblowing Legislation, Transparency International, 2018, https://www.transparency.org/en/publications/best-practice-guide-for-whistleblowing-legislation, accessed 01/09/2021. 
Transparency International (2019), Building on the EU Directive for whistleblower protection, Analysis and Recommendations, Position Paper, 1/2019, https://www.transparency.org/ en/publications/building-on-the-eu-directive-for-whistleblower-protection, accessed 01/09/2021.

Vandekerckhove W., Is It Freedom? The Coming About of the EU Directive on Whistleblower Protection, Journal of Business Ethics, https://doi.org/10.1007/s10551-021-04771-x accessed 01/09/2021.

Vuksanović I., Poziv za specialno zakonsko ureditev "žvižgačev« (Call for special regulation of "whistleblowers"), Pravna praksa, 2010/45.

Wygoda K., Wasiak D., Poufność informacji o sygnaliście jako ultima ratio systemu compliance (Confidentiality of information about the whistleblower as the ultima ratio of the compliance system), [in:] B. Baran B., M. Ożóg (eds.), Ochrona sygnalistów. Regulacje dotyczace osób zgłaszających nieprawidłowości (Whistleblower Protection. Regulations Concerning Persons Reporting Irregularities), Wolters Kluwer, Warsaw 2021. 